\title{
Examination of genetic variants involved in generation and biodisposition of kinins in patients with angioedema
}

\author{
Jonathan Levy ${ }^{1 *}$, Georges-Etienne Rivard² ${ }^{2}$ Eric Wagner ${ }^{3}$, Don Beezhold ${ }^{4}$, Noam Berlin $^{5}$, Li Fan², Zhao Zhang ${ }^{2}$ \\ and Gordon L Sussman ${ }^{5}$
}

\begin{abstract}
Background: Angioedema (AE) is idiopathic in the majority of cases. We studied patients with AE for genetic variants of proteins involved with bradykinin generation and biodisposition.

Methods: One hundred sixty one patients with AE were recruited at a university hospital clinic. Patients were categorized according to the proposed pathogenesis of AE: low C1 inhibitor ( $\mathrm{C} 1-\mathrm{INH})$ and $\mathrm{C} 4$ levels, autoimmune disease, cancer, angiotensin-converting enzyme (ACE) inhibitor-induced, nonsteroidal antiinflammatory drug (NSAID)-induced, or idiopathic. In addition, each patient had a blood sample analyzed for a complement profile and enzymes (C1-INH and C4). Fifty-two of the patients were tested for genetic variants in factor XII, plasminogen-activator inhibitor-1 (PAI-1), ACE, and aminopeptidase P (APP).

Results: The cause of angioedema was identified in 59/161 (37\%) of the cases: 3 (2\%) patients had a low plasma C1-INH and C4; 20 (12\%) were ACE inhibitor-induced; 12 (7\%) were associated with autoimmune disorders; 7 (4\%) were associated with malignancy; and 17 (11\%) were associated with NSAIDs. In the remaining 102 (63\%) patients the cause of angioedema was idiopathic. Of 52 patients with genetic analysis, 13 (25\%) had a genetic variant in APP, 10 (19\%) in ACE, 13 (25\%) in PAl-1, and 0 in Factor XII.

Conclusions: In addition to related diseases and medications causing $A E$, certain genetic variants encoding proteins involved in bradykinin generation and/or catabolism pathways may be involved in the pathogenesis of $A E$.
\end{abstract}

Keywords: Angioedema, Plasminogen-activator inhibitor-1, Aminopeptidase P, Angiotensin-converting enzyme, Factor XII

\section{Background}

Angioedema (AE) is a self-limited swelling in the dermis, subcutaneous tissue, mucosa, and submucosa that can last for hours to days [1]. It is a potentially life-threatening disease in cases of laryngeal AE. The pathophysiology differs from urticaria, which involves the epidermis and dermis. Several variants of angioedema exist making diagnosis and initiating appropriate treatment difficult.

\footnotetext{
* Correspondence: levy1@ualberta.ca

'Division of Dermatology and Cutaneous Sciences, University of Alberta, 2-166 Clinical Sciences Building, 11350 - 83 Avenue, Edmonton, Alberta T6G 2G3, Canada

Full list of author information is available at the end of the article
}

$\mathrm{AE}$ can be broadly categorized as those presenting with and without associated urticaria. AE with urticaria is occasionally allergic and due to food, medication, latex, insect venom, or radiocontrast media [2], but many cases are idiopathic [3]. AE without urticaria can be non-histamine mediated due to $\mathrm{C} 1$ inhibitor (C1-INH) deficiency (hereditary or acquired), or related to angiotensin converting enzyme (ACE) inhibitor use, autoimmune diseases, malignancies, or nonsteroidal anti-inflammatory drug (NSAID) use, but in many cases is idiopathic.

Hereditary angioedema (HAE) is caused by mutations in Serping1, which encodes C1-INH, a serine protease inhibitor that regulates activation of the classical and lectin (and possibly the alternative) complement pathways and 
the contact activation pathway of the coagulation system [4]. Pattern of inheritance is autosomal dominant in the vast majority of affected patients who generally have partial C1-INH deficiency $[5,6]$ and cannot efficiently control the contact activation system. Type I HAE is due to low circulating levels of functional $\mathrm{C} 1-\mathrm{INH}$, whereas type II is due to normal to high levels of non-functional C1-INH. Recently, HAE with normal C1-INH (type III) has been described as an estrogen-related hereditary form with normal functional levels of C1-INH and affecting predominantly women who sometimes have a gain of function variant of the gene coding for coagulation factor XII [7]. An acquired form of C1-INH deficiency also leads to $\mathrm{AE}$ and is seen in patients with autoimmune disease or certain malignancies [8]. Diagnosis of acquired C1-INH deficiency requires a negative family history and its onset is usually after the $4^{\text {th }}$ decade of life, in contrast to hereditary C1-INH deficiency. It is associated occasionally with antibodies that react in vitro to $\mathrm{C} 1-\mathrm{INH}$. AE due to ACE inhibitor or NSAID use may present without urticarial involvement or in concurrence with chronic spontaneous urticaria, which is defined as urticaria occurring for at least six weeks due to an endogenous cause and not external physical stimuli [9]. In many patients, AE occurs in the absence of any known cause [10].

Non-histaminergic angioedema is most likely caused by the generation of bradykinin, a potent vasoactive peptide $[11,12]$. Bradykinin is generated mainly through activation of the contact system (Figure 1). Upon activation, factor XII cleaves prekallikrein into kallikrein, which in turn cleaves high molecular weight kininogen to free the potent bradykinin peptide. Another pathway through which bradykinin can be generated is via the fibrinolysis pathway, although at a lesser extent. Indeed, plasmin, generated from plasminogen by the action of the plasminogen activators, tissue plasminogen activator and urokinase-like plasminogen activator, can cleave high molecular weight kininogen into bradykinin. Activity of tissue plasminogen activator and urokinase-like plasminogen activator is inhibited by plasminogen-activator inhibitor-1 (PAI-1) [13]. Bradykinin is short-lived and rapidly transformed by carboxypeptidase $\mathrm{N}$ into a bioactive intermediate des-Arginine- 9 bradykinin and/or bioinactive intermediates by ACE and aminopeptidases $\mathrm{P}$ (APP) [14] and M.

We hypothesize that defects in factors involved in bradykinin generation or its catabolism may be associated with $\mathrm{AE}$ attacks. This has been demonstrated in patients who present with AE with neither C1-INH deficiency nor any other known cause [10]. Some patients exhibit gainof-function mutations in factor XII that are suggested to lead to increased activity, therefore increasing bradykinin generation upon contact system activation [15]. Also, polymorphisms affecting genes encoding ACE and APP have been associated with increased levels of bradykinin and/or des-Arg-9 bradykinin presumably related to reduced biodegradation [16]. Occurrence of these polymorphisms in addition to mutations in factor XII has been shown in patients with estrogen-related AE [17]. Polymorphisms in XPNPEP2, which encodes APP, have been associated with ACE inhibitor-associated AE [18,19]. Further, polymorphisms in PAI-1 are known in humans [20] that

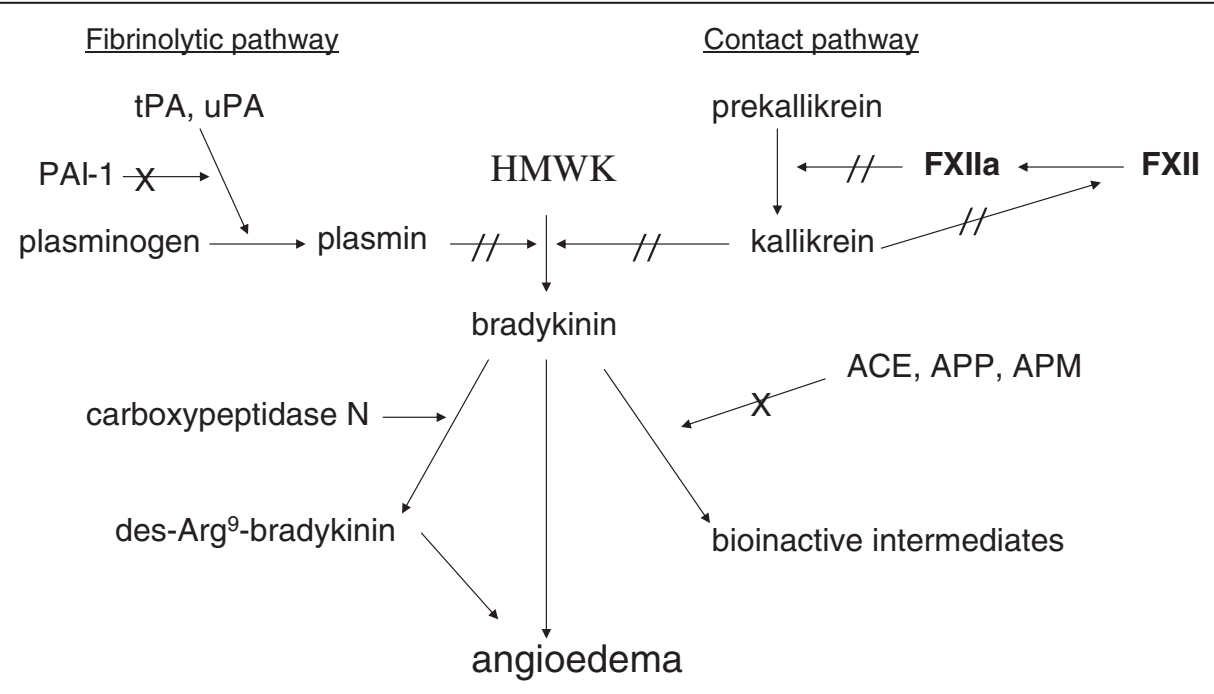

Figure 1 The fibrinolytic and contact pathways demonstrating the generation and catabolism of bradykinin, which clinically may present as angioedema. HMWK, high molecular weight kininogen; tPA, tissue plasminogen activator; UPA, urokinase-like plasminogen activator; PAI-1, plasminogen activator inhibitor-1; FXII, factor XII; ACE, angiotensin converting enzyme; APP, aminopeptidase P; APM, aminopeptidase M. The effect of $\mathrm{C} 1$ inh was not included. //, blocked by $\mathrm{C} 1-\mathrm{INH}, \mathrm{C1}$ inhibitor; $\mathrm{X}$, negative regulation. 
theoretically could be associated with $\mathrm{AE}$ in some patients by allowing increased generation of plasmin. The 5G variant is associated with less inhibition of plasminogen activators and, consequently, increased conversion of plasminogen to plasmin [21] and potentially more generation of bradykinin.

We studied patients with $\mathrm{AE}$ by genetic analysis for variants in genes encoding proteins involved in bradykinin generation (factor XII, PAI-1) and enzymes involved in bradykinin catabolism (ACE, APP). A further objective was to classify patients according to etiology: decreased levels of C1-INH and C4, ACE inhibitor-induced, autoimmune disease, malignancy, NSAID-induced, or idiopathic.

\section{Methods}

One hundred sixty-one patients presenting with $\mathrm{AE}$ at a university hospital clinic were recruited. Diagnosis of AE was made by an expert physician (GLS) based on clinical history and direct physical examination. All patients provided informed written consent and ethics approval was received through a research ethics board (Canadian SHIELD, Burlington, ON, Canada). We obtained a detailed clinical history including the location of AE (central, peripheral, laryngeal, and/or abdominal), family history of $\mathrm{AE}$ and other autoimmune disorders, malignancies, autoimmune diseases, use of ACE inhibitor or NSAID, and associated urticaria. Routine skin prick tests to common airborne and environmental allergens were done (ALK-Abelló, Port Washington, NY). Each patient had a blood sample analyzed for antigenic and functional levels of $\mathrm{C} 1-\mathrm{INH}$ and antigenic levels of C4. C1-INH levels were measured either by immunonephelometry (Beckman Coulter, Brea, CA) or radial immunodiffusion (The Binding Site, San Diego, CA) and C4 levels were assessed using immunonephelometry (Beckman Coulter). C1-INH function was measured using a standard chromogenic assay (Berichrom C1-INH, Siemens, Erlangen, Germany). Patients were then categorized according to the proposed pathogenesis of $\mathrm{AE}$ : low C1-INH and C4 levels, ACE inhibitor-induced, autoimmune disease, malignancy, NSAID-induced, or idiopathic. Blood specimens suitable for DNA extraction were available from 52 of the 161 patients. They were tested for specific genetic variants in genes encoding proteins or enzymes involved in direct or indirect regulation of bradykinin generation and catabolism, specifically factor XII, PAI-1, ACE, and APP. DNA samples were analysed by standard molecular techniques looking for the following genetic variants: factor XII (mutation c.1032C $>$ A or c.1032C $>$ G), PAI-1 (4G/ 5G polymorphism), ACE (insertion/deletion I/D polymorphism, Single Nucleotide Polymorphism Database (dbSNP): rs1799752), APP (deletion g.2953-3127del, single nucleotide polymorphism (SNP) c.-2399C > A, dbSNP: rs3788853).

Whole blood was collected in EDTA and stored at $-80^{\circ} \mathrm{C}$ until used. Genomic DNA was extracted with the Qiagen DNA extraction kit (Qiagen, California, USA). Each sample was tested for 6 target genetic variants in 4 different genes (XPNPEP2, ACE, F12, Serpine 1).

\section{Polymorphism and deletion in Aminopeptidase $\mathbf{P}$}

For Aminopeptidase P (APP), the gene XPNPEP2 is located in chromosome Xq26.1. A polymorphism (c.-2399C > A) is in the promoter region, while a 175 -bp deletion is in exon 2 (g.2953-3127del) [22].

The primers for c.-2399C > A were: forward APP-SNP2 F $5^{\prime}$-TCC CCG TTT AGT TTG TTT GC-3', reverse APP-SNP-1R 5'-GGG CTA ATG TTG GTG ATG CT3'. 100 ng genomic DNA was subjected to PCR with $200 \mu \mathrm{M}$ of dNTP, $1.5 \mathrm{mM}$ of $\mathrm{MgCl} 2,1 \mu \mathrm{M}$ of primers, $1.25 \mathrm{U}$ of Taq DNA polymerase Gold (ABI, Burlington, ON, Canada), $1 \mathrm{X}$ buffer in a final volume of $25 \mu \mathrm{l}$ in ABI 9700 thermal cycler. The DNA was denatured at $95^{\circ} \mathrm{C}$ for $8 \mathrm{~min}$ followed with 35 cycles of $94^{\circ} \mathrm{C}$ for $50 \mathrm{sec}$, $56^{\circ} \mathrm{C}$ for $50 \mathrm{sec}$, and $72^{\circ} \mathrm{C}$ for $1 \mathrm{~min}$. The extension is at $72^{\circ} \mathrm{C}$ for $10 \mathrm{~min}$. Amplicons of PCR were sequenced to detect this polymorphism.

The primers for g.2953-3127del were: forward APPdel3 F1 (5'-TTT CTC CCG GCT TCT AGC TT-3'), and reversed primer APPdel-3R0 (5'-CTC AGC CAA AGG CCA GTT AG-3'). $150 \mathrm{ng}$ genomic DNA is subject to PCR with $400 \mu \mathrm{M}$ of dNTP, $0.8 \mu \mathrm{M}$ of primers, $1 \mathrm{M}$ of betaine and 1.6U of long bp Taq DNA polymerase ELT (Roche, Indianapolis, IN, USA), $1 \mathrm{X}$ buffer \#2 in a final volume of $30 \mu \mathrm{l}$. The DNA was first denatured at $95^{\circ} \mathrm{C}$ for $7 \mathrm{~min}$, cooled on ice, then with brief centrifugation, followed by 35 cycles of $94^{\circ} \mathrm{C}$ for $3 \mathrm{~min}, 94^{\circ} \mathrm{C}$ for $50 \mathrm{sec}$, $63^{\circ} \mathrm{C}$ for $50 \mathrm{sec}, 72^{\circ} \mathrm{C}$ for $1 \mathrm{~min}$, and extension at $72^{\circ} \mathrm{C}$ for $10 \mathrm{~min}$.

\section{ACE polymorphism}

The ACE gene encodes the angiotensin-converting enzyme (ACE). An insertion/deletion (I/D) polymorphism is located in intron 16 of the gene. This polymorphism is characterized by the presence (called I allele) or absence (called D allele) of a $287 \mathrm{bp}$ Alu repeat sequence. In Caucasians, the I allele is associated with lower, and the D allele with higher circulating ACE activity, respectively. The heterozygotes for insertion/deletion (I/D) present about one-half of the variance of the activity [23].

Forward primer ACE-I/D-F was 5'-CTG GAG AGC CAC TCC CAT CCT TTCT-3', reverse primer ACE-I/D$\mathrm{R}$ is $5^{\prime}$ - GAC GTG GCC ATC ACA TTC GTC AGA - 3 '. 
150 ng genomic DNA was subject to PCR with $400 \mu \mathrm{M}$ of dNTP, $0.8 \mu \mathrm{M}$ of primers ACE-I/D-F and ACE-I/D-R, $1 \mathrm{M}$ of betaine and $1.6 \mathrm{U}$ of long bp Taq DNA polymerase ELT, $1 \mathrm{X}$ buffer \#2 (Roche, Indianapolis, IN, USA) in a final volume of $30 \mu \mathrm{l}$. The DNA was denatured at $95^{\circ} \mathrm{C}$ for $7 \mathrm{~min}$, cooled on ice before brief centrifugation, followed by 35 cycles of $94^{\circ} \mathrm{C}$ for $3 \mathrm{~min}, 94^{\circ} \mathrm{C}$ for $50 \mathrm{sec}$, $63^{\circ} \mathrm{C}$ for $50 \mathrm{sec}, 72^{\circ} \mathrm{C}$ for $1 \mathrm{~min}$, and extension at $72^{\circ} \mathrm{C}$ for $10 \mathrm{~min}$.

\section{Factor XII mutation}

The F12 gene encodes coagulation factor XII (Hageman factor). Mutations c. $1032 \mathrm{C}>\mathrm{A}$ and c. $1032 \mathrm{C}>\mathrm{G}$ are located in exon 9 of the F12 gene. Forward primer FXIIex9-F2 was 5'-CTG GGA GTA CTG CGA CCT G-3', reverse primer FXII-ex9-R1 was 5'- AAG GCT GTG GAG GAG CAG -3'. One hundred fifty ng no of genomic DNA DNA was subject to PCR with $200 \mu \mathrm{M}$ of $\mathrm{dNTP}, 1 \mu \mathrm{M}$ of primers, $1.5 \mathrm{mM}$ of $\mathrm{MgCl} 2,1.25 \mathrm{U}$ of Taq DNA polymerase $(\mathrm{ABI}), 1 \mathrm{X}$ buffer, in a final volume of $30 \mu$. The PCR reaction started with denaturation at $94^{\circ} \mathrm{C}$ for $10 \mathrm{~min}$, followed by 35 cycles at $94^{\circ} \mathrm{C}$ for $50 \mathrm{sec}, 63^{\circ} \mathrm{C}$ for $50 \mathrm{sec}, 72^{\circ} \mathrm{C}$ for $1 \mathrm{~min}$, then extension at $72^{\circ} \mathrm{C}$ for $10 \mathrm{~min}$. Amplicons generated were then sequenced.

\section{PAI-1 polymorphism}

Plasminogen activator inhibitor-1 is encoded by the Serpine 1 gene. The 4G/5G polymorphism is located in the promoter region. The 4G/4G genotype leads to a significantly higher PAI-1 plasma concentration than the $4 \mathrm{G} / 5 \mathrm{G}$ and $5 \mathrm{G} / 5 \mathrm{G}$ genotypes.

Forward primer serpine 1-F2 was $5^{\prime}$-CAC AGA GAG AGT CTG GCC ACG T-3', reverse primer serpine 1-R4 was 5'-CCA ACA GAG GAC TCT TGG TCT-3'. One hundred fifty ng of genomic DNA was subjected to PCR with $200 \mu \mathrm{M}$ of dNTP, $1 \mu \mathrm{M}$ of primers, $1.5 \mathrm{mM}$ of

Table 1 Demographics of patients with angioedema

\begin{tabular}{llll}
\hline & & Entire cohort & $\begin{array}{l}\text { Subgroup of } \\
\text { patients with } \\
\text { genetic testing }\end{array}$ \\
\hline $\begin{array}{l}\text { Number of patients } \\
\text { Mean age (years) }\end{array}$ & & 161 & 52 \\
Gender & 50.6 & 52.3 \\
Presumed etiology & $\downarrow$ C1-INH, C4 & $3(1.9 \%)$ & $0(0 \%)$ \\
& ACE-inhibitor & $20(12.4 \%)$ & $3(5.8 \%)$ \\
& Malignancy & $7(4.3 \%)$ & $3(5.8 \%)$ \\
& Autoimmune & $12(7.5 \%)$ & $5(9.6 \%)$ \\
& NSAID & $17(10.6 \%)$ & $2(3.8 \%)$ \\
& Idiopathic & $102(63.4 \%)$ & $39(75 \%)$ \\
\hline
\end{tabular}

C1-INH, C1 inhibitor; ACE-inhibitor, Angiotensin converting enzyme-inhibitor; NSAID, Nonsteroidal anti-inflammatory drug.
$\mathrm{MgCl} 2,1.25 \mathrm{U}$ of Taq DNA polymerase (ABI), 1X buffer, in a final volume of $30 \mu \mathrm{l}$. The PCR reaction is initiated by denaturation at $94^{\circ} \mathrm{C}$ for $10 \mathrm{~min}$, followed by 30 cycles at $94^{\circ} \mathrm{C}$ for $1 \mathrm{~min}, 63^{\circ} \mathrm{C}$ for $1 \mathrm{~min}, 72^{\circ} \mathrm{C}$ for $2 \mathrm{~min}$, and extension at $72^{\circ} \mathrm{C}$ for $10 \mathrm{~min}$. The PCR amplicons were digested by restriction enzyme Bs1I for 3 hours followed by separation in a $3 \%$ agarose gel [24].

\section{Results}

One hundred sixty-one patients between the ages of 14 and 86 presented with AE (Table 1). Sixty-four patients were male and 97 were female with a mean age of 51 years. Eighty-one percent of patients were of European descent, 15 percent were South Asian, and 4 percent were African Caribbean. The cause of AE was identified in 59 (37\%) cases: $3(2 \%)$ patients had a low plasma $\mathrm{C} 1-\mathrm{INH}$ and $\mathrm{C} 4$ levels; 20 (12\%) were ACE inhibitor-induced;12 (7\%) were associated with autoimmune disorders; 7 (4\%) were associated with malignancy; and 17 (11\%) were related to use of NSAIDs. In the remaining 102 (63\%) patients, the cause of AE was idiopathic. Atopy was not identified as a trigger of angioedema in any of the patients. From the entire cohort 67 (42\%) patients experienced associated urticaria with their AE which may be typical chronic spontaneous urticaria, while the remaining 94 (58\%) did not. In all patients the urticaria was a remote event and not considered related to the angioedema with which they presented.

Fifty-two patients out of 161 had genotyping performed. In this group, there were 22 males and 30 females ranging from 24 to 88 years old, with a mean age of 53 years. As seen in Table 2, 13 of the 52 (25\%) patients had an identifiable cause: 3 were associated ACE inhibitor use, 3 with malignancy, 5 with autoimmune disease, 2 with NSAID use, and no patients with low $\mathrm{C} 1-\mathrm{INH}$ and $\mathrm{C} 4$ levels. In these patients with a known etiology there were a total of 7 mutations/polymorphisms in 6 individuals: 2 in APP (SNP -2399C > A, dbSNP: rs3788853), 1 in ACE (insertion/deletion I/D polymorphism, dbSNP: rs1799752), 2 in PAI-1 (5G/5G polymorphism), and 1 in both ACE and PAI-1.The deletions g.2953-3127 in APP and c.1032C > A or c. $1032 \mathrm{C}>\mathrm{G}$ in factor XII were not detected in any patient. Those with idiopathic AE comprised the remaining 39 (75\%) patients. Of these patients, 11 had a genetic variant in APP (SNP -2399C > A, dbSNP: rs3788853), 8 in ACE, 10 in PAI-1, and none in APP (deletion g.2953$3127 \mathrm{del}$ ) or factor XII. These 29 genetic variants were present in 22 of the idiopathic patients, as 7 of the patients had variants in 2 different genes. Thus 22 of the 39 patients with idiopathic $\mathrm{AE}$ had a mutation or polymorphism in one of the studied genes. Of all 52 patients tested, $13(25 \%)$ patients had a specific genetic variant in APP (SNP -2399C > A, dbSNP: rs3788853), 10 (19\%) in ACE, 13 (25\%) in PAI-1, and none in APP (deletion g.2953- 
Table 2 Patients with a specific genetic variant categorized by presumed etiology

\begin{tabular}{|c|c|c|c|c|c|c|c|}
\hline \multirow{2}{*}{$\begin{array}{l}\text { Genetic variant } \\
\text { Presumed etiology } \\
\text { (n) }\end{array}$} & \multirow{2}{*}{$\begin{array}{l}\text { APP (deletion) } \\
\text { (deletion) }\end{array}$} & \multicolumn{2}{|l|}{ APP (SNP) } & \multirow{2}{*}{$\begin{array}{l}\text { ACE } \\
\text { (I/I polymorphism) }\end{array}$} & \multirow{2}{*}{$\begin{array}{l}\text { PAI-1 } \\
\text { (5G/5G polymorphism) }\end{array}$} & \multirow{2}{*}{$\begin{array}{l}\text { Factor XII } \\
(C / A, A, C / G \text {, or } G)\end{array}$} & \multirow{2}{*}{$\begin{array}{l}\text { Total number } \\
\text { of patients with } \\
\text { at least one } \\
\text { genetic variant* }\end{array}$} \\
\hline & & (C/A) & (A) & & & & \\
\hline ACE-inhibitor (3) & 0 & 0 & 0 & 0 & 1 (1.9\%) & 0 & $1(1.9 \%)$ \\
\hline Malignancy (3) & 0 & 1 (1.9\%) & 0 & 0 & 0 & 0 & 1 (1.9\%) \\
\hline Autoimmune (5) & 0 & 0 & 0 & $2(3.8 \%)$ & $2(3.8 \%)$ & 0 & $3(5.8 \%)$ \\
\hline NSAID (2) & 0 & 0 & $1(1.9 \%)$ & 0 & 0 & 0 & 1 (1.9\%) \\
\hline Idiopathic (39) & 0 & 7 (13.5\%) & $4(7.7 \%)$ & 8 (15.4\%) & 10 (19.2\%) & 0 & 22 (42.3\%) \\
\hline Total (52) & 0 & $8(15.4 \%)$ & $5(9.6 \%)$ & 10 (19.2\%) & $13(25 \%)$ & 0 & $28(53.8 \%)$ \\
\hline
\end{tabular}

APP, Aminopeptidase P; ACE, Angiotensin-converting enzyme; PAI-1, Plasminogen-activator inhibitor-1; NSAID, Nonsteroidal anti-inflammatory drug; SNP, Single nucleotide polymorphism. Specific genetic variants were tested in the following genes: APP(deletion g.2953-3127del); APP, (SNP -2399C > A, dbSNP: rs3788853); ACE(insertion/deletion I/D polymorphism, dbSNP: rs1799752)); PAI-1(4G/5G polymorphism); Factor XII( mutations c.1032C > A or C.1032C > G). ${ }^{*}$ Some patients had a genetic variant in multiple genes. Note: only significant genetic variants are reported, as indicated in title row.

Abbreviations: $A E$ angioedema, $C 1$-INH, C1-inhibitor, ACE angiotensin converting enzyme, NSAID nonsteroidal anti-inflammatory drug, HAE hereditary angioedema, $P A l-1$ plasminogen-activator inhibitor-1, APP aminopeptidase $\mathrm{P}$.

3127del) or Factor XII. Of the entire cohort, genetic variants in multiple genes were present in 9 patients.

\section{Discussion}

Several classifications of $\mathrm{AE}$ have been suggested over the last few decades [10,17,25-27]. These include C1-INH deficiency, use of medications such as ACE inhibitors or NSAIDs, as well as autoimmune conditions and malignancies. Recently, a new classification of AE has been proposed by an international group of experts [10]. It is based on the pattern of presentation (familial or sporadic) and level of C1-INH (normal or low). In some cases, the underlying cause can be identified. Once the offending medication has been discontinued or the underlying disease has been treated, the AE typically resolves, thus confirming the causative factor. However, in many cases no underlying cause is found and the AE is labeled as idiopathic. This of course makes treatment decisions more difficult as there is no specific treatment available. In our cohort, $63 \%$ of patients had idiopathic AE; however, while the proportion of patients with idiopathic $\mathrm{AE}$ is not clearly reported in the literature a relatively high rate is suspected by many centers [10]. The underlying etiology should help guide treatment decisions. Therefore, discovering the etiology in those with idiopathic AE could lead to better targeted therapeutic options in these patients. We tested 52 patients with AE for genetic variants in genes encoding 4 proteins involved in the regulation of bradykinin generation or catabolism. Fifty-six percent of patients with idiopathic AE had at least one genetic variant. Given these findings we believe that a genetic predisposition could be considered in some patients with AE: the presence of mutations or polymorphisms in factors involved in generation and/or biodisposition of kinins.

Our cohort of 161 patients revealed that most present with AE not related with C1-INH deficiency. Indeed, only three patients demonstrated acquired angioedema with diminished levels of C1-INH. In all three cases the $\mathrm{AE}$ was linked to lymphoma and they each had a negative family history for angioedema. The vast majority of patients are thus without effective specific etiology-based treatment for either prophylaxis or acute episodes. The presence of the genetic abnormalities we tested for could help explain the occurrence of $\mathrm{AE}$ in many patients and help better establish treatment options that could supplement standard treatment. For example, a specific inhibitor of kallikrein (Ecallantide) and/or a bradykinin B2 receptor antagonist (Icatibant) could be used in patients with $\mathrm{AE}$ not caused by C1-INH deficiency. Some reports show that use of C1-INH concentrates or Icatibant in patients with $\mathrm{AE}$ not linked to C1-INH deficiency have mixed results. Response to treatment may depend on the underlying mutation/polymorphism [10]. In those with genetic variants of PAI-1, reduced or dysfunctional protein could lead to more active fibrinolysis and presumably increased generation of bradykinin. Antifibrinolytic agents, such as tranexamic acid and $\varepsilon$-aminocaproic acid, could be considered as a treatment of choice in these patients. In the case of HAE or acquired AE, these medications could supplement $\mathrm{C} 1-\mathrm{INH}$ concentrates as the clinical presentation, severity, and frequency of $\mathrm{AE}$ attacks vary in patients with C1-INH deficiency, which may be explained by genetic variants present in those patients. Angioedema occurs in association with various clinical settings but the risk and severity of attacks could be linked to the presence of an allelic variant in one of the molecules involved in bradykinin generation and/or catabolism. As new genetic variants are discovered, more therapies can be developed to target the implicated proteins.

It is possible that the genetic variants that we identified may actually be risk factors to developing AE. For instance, the presence of the $5 \mathrm{G} / 5 \mathrm{G}$ polymorphism associated with a low level of PAI-1 leading to higher level of generation of plasmin may predispose someone to 
developing $\mathrm{AE}$ in the presence of therapy with $\mathrm{ACE}$ inhibitors which decrease the biodisposition of kinins. Similar rationale can be applied to those with $\mathrm{AE}$ secondary to malignancy, autoimmune disease, or NSAID use. Polymorphisms in APP and ACE lead to decreased bradykinin biodegradation, whereas gain-of-function mutations in factor XII increase its production.

One limitation of our study is that a control group was not tested. Evaluation of the frequency of gene variant occurrence in a control population would be helpful in assessing a potential role in development of AE. However, allele frequencies are highly influenced by ethnicity, as reported for some variants we tested for such as PAI-1 $[20,28]$ and ACE [29]. Only specific polymorphisms/mutations in APP, ACE, PAI-1, and factor XII were tested. It is likely that other regions of these genes or other genes involved in the kinin-generating pathway may have variants affecting protein function that can lead to altered regulation of bradykinin. Based on European populations, for the SNP -2399 C $>$ A ( $r s 3788853)$, the frequency of allele C is $73 \%$, while the frequency of allele $\mathrm{A}$ is $26 \%$ [30]. For the 4G/5G PAI-1 gene polymorphism, the frequency of $4 \mathrm{G}$ is $50 \%$ and the frequency of $5 \mathrm{G}$ is $50 \%[20,28]$. For the I/D polymorphism (rs1799752) in the ACE gene, the frequency of D is 50\% in Northern Europeans and 52\% in Southern Europeans, respectively, while the frequency of I is $50 \%$ in Northern Europeans and 48\% in Southern Europeans, respectively [29]. In our patients presenting with angioedema these genetic variants, by themselves or in association with other unknown cofactors, such as stress or trauma, can be responsible for their clinical manifestations. This is an investigative study that probes novel genetic mutations and polymorphisms and requires further work with a larger population size. Nonetheless, this research directs future studies on this poorly understood group of disorders of bradykinin metabolism. These results demonstrate genetic variants that would affect patients presenting with angioedema.

\section{Conclusions}

Our study explored the possibility that defects in genes encoding proteins involved in kinin generation or catabolism other than $\mathrm{C} 1$ inhibitor may be involved in angioedema. This data suggests that a high proportion of patients with angioedema may have various defective protein functions leading to sustained bradykinin effects upon triggering of its generation in AE. Functional studies addressing this possibility would be warranted.

Our preliminary observations support the hypothesis that the occurrence of $\mathrm{AE}$ attacks could be facilitated by a variety of a variety of variants in genes encoding proteins involved in generation and/or biodisposition of kinins known to be mediators of this clinical syndrome. A high proportion of patients may present with genetic variants, which needs to be verified in further studies.

In the future, patients with unusual phenotypes of $\mathrm{AE}$, including those with reduced C1-INH function, could be investigated for gene variants associated with bradykinin generation and degradation that are likely to contribute to their clinical syndrome. Results of such studies could help understand the pathophysiology of this clinically variable syndrome. This could eventually lead to more effective personalized therapy and prevention of attacks.

\section{Abbreviations}

AE: Angioedema; C1-INH: C1 inhibitor; ACE: Angiotensin converting enzyme; NSAID: Nonsteroidal anti-inflammatory drug; HAE: Hereditary angioedema; PAI-1: Plasminogen-activator inhibitor-1; APP: Aminopeptidase P; dbSNP: Single nucleotide polymorphism database; SNP: Single nucleotide polymorphism.

\section{Competing interests}

The authors declare that they have no competing interests.

\section{Authors' contributions}

$J \mathrm{~L}$ conceived and coordinated the study, recruited patients, analyzed data and wrote the manuscript. GER conceived of the study, participated in its design and coordination, analyzed the data and helped to draft the manuscript. EW conceived of the study, participated in its design and and coordination, performed the radial immunodiffusion and chromogenic assays, analyzed the data and helped to draft the manuscript. DB participated in the design and coordination of the study, analyzed the data, and helped to draft the manuscript. NB participated in the coordination of the study, and generation and analysis of the patient data. LF participated in performing the radial immunodiffusion, chromogenic assays, and analysis of DNA samples, and helped to draft the manuscript. ZZ participated in performing the immunonephelometry, radial immunodiffusion, chromogenic assays, and analysis of DNA samples. GLS conceived of the study, participated in its design and coordination, recruited patients, analyzed the data and helped to draft the manuscript. All authors read and approved the final manuscript.

\section{Acknowledgements}

GER received support from Bayer's Funds for Centre of Excellence in Paediatric Haemostasis. This study was funded in part by a Centers for Disease Control (CDC)-National Institute of Environmental Health Sciences (NIEHS) inter agency agreement (IAA \# AES12007001-1-0-6).

\section{Author details}

${ }^{1}$ Division of Dermatology and Cutaneous Sciences, University of Alberta, 2-166 Clinical Sciences Building, 11350 - 83 Avenue, Edmonton, Alberta T6G 2G3, Canada. ${ }^{2} \mathrm{CHU}$ Sainte-Justine, Université de Montréal, Montreal, QC, Canada. ${ }^{3} \mathrm{CHU}$ de Québec and UniversitéLaval, Quebec City, QC, Canada. ${ }^{4}$ National Institute for Occupational Safety and Health, Morgantown, WV, Canada. ${ }^{5}$ University of Toronto, Toronto, ON, Canada.

Received: 30 June 2014 Accepted: 14 November 2014

Published online: 12 December 2014

\section{References}

1. Kaplan AP, Greaves MW: Angioedema. J Am Acad Dermatol 2005, 53:373-388

2. Szebeni J: Complement activation-related pseudoallergy: a new class of drug-induced acute immune toxicity. Toxicology 2005, 216:106-121.

3. Frigas E, Nzeako UC: Angioedema. pathogenesis, differential diagnosis, and treatment. Clin Rev Allergy Immunol 2002, 23:217-231.

4. Wagner E, Frank MM: Therapeutic potential of complement modulation. Nat Rev Drug Discov 2010, 9:43-56.

5. Blanch A, Roche O, Urrutia I, Gamboa P, Fontán G, López-Trascasa M: First case of homozygous C1 inhibitor deficiency. J Allergy Clin Immunol 2006, 118:1330-1335.

6. Bowen T, Cicardi M, Farkas H, Bork K, Longhurst HJ, Zuraw B, Aygoeren-Pürsün E, Craig T, Binkley K, Hebert J, Ritchie B, Bouillet L, Betschel S, Cogar D, Dean J, 
Devaraj R, Hamed A, Kamra P, Keith PK, Lacuesta G, Leith E, Lyons H, Mace S, Mako B, Neurath D, Poon MC, Rivard GE, Schellenberg R, Rowan D, Rowe A, et al: International consensus algorithm for the diagnosis, therapy and management of hereditary angioedema. Allergy Asthma Clin Immunol 2010, 2010(6):24-37.

7. Bork K, Wulff K, Hardt J, Witzke G, Staubach P: Hereditary angioedema caused by missense mutations in the factor XII gene: clinical features, trigger factors, and therapy. J Allergy Clin Immunol 2009, 124:129-134.

8. Agostoni A, Cicardi M: Hereditary and acquired C1 inhibitor deficiency: biological and clinical characteristics in 235 patients. Medicine 1992, 71:206-215

9. Zuberbier T, Asero R, Bindslev-Jensen C, Walter Canonica G, Church MK, Giménez-Arnau A, Grattan CE, Kapp A, Merk HF, Rogala B, Saini S, Sánchez-Borges M, Schmid-Grendelmeier P, Schünemann H, Staubach P, Vena GA, Wedi B, Maurer M, Dermatology Section of the European Academy of Allergology and Clinical Immunology, Global Allergy and Asthma European Network, European Dermatology Forum, World Allergy Organization: EAACI/GA(2)LEN/EDF/WAO guideline: definition, classification and diagnosis of urticaria. Allergy 2009, 64:1417-1426.

10. Zuraw BL, Bork K, Binkley KE, Banerji A, Christiansen SC, Castaldo A, Kaplan A, Riedl M, Kirkpatrick C, Magerl M, Drouet C, Cicardi M: Hereditary angioedema with normal C1 inhibitor function: consensus of an international expert panel. Allergy Asthma Proc 2012, 33(Suppl 1):145-156.

11. Cugno M, Nussberger J, Cicardi C, Agostoni A: Bradykinin and the pathophysiology of angioedema. Int Immunopharmacol 2003, 3:311-317.

12. Farkas $\mathrm{H}$ : Current pharmacotherapy of bradykinin-mediated angioedema. Expert Opin Pharmacother 2013, 14:571-586.

13. Lijnen HR, Collen D: Mechanisms of physiological fibrinolysis. Baillieres Clin Haematol 1995, 8:277-290.

14. Moreau ME, Garbacki N, Molinaro G, Brown NJ, Marceau F, Adam A: The kallikrein-kinin system: current and future pharmacological targets. J Pharmacol Sci 2005, 99:6-38.

15. Cichon S, Martin L, Hennies HC, Müller F, Van Driessche K, Karpushova A, Stevens W, Colombo R, Renné T, Drouet C, Bork K, Nöthen MM: Increased activity of coagulation factor XII (Hageman factor) causes hereditary angioedema type III. Am J Hum Genet 2006, 79:1098-1104.

16. Duan QL, Binkley K, Rouleau GA: Genetic analysis of factor XII and bradykinin catabolic enzymes in a family with estrogen-dependent angioedema. J Allergy Clin Immunol 2009, 123:906-910.

17. Caballero T, Baeza ML, Cabañas R, Campos A, Cimbollek S, Gómez-Traseira C, González-Quevedo T, Guilarte M, Jurado-Palomo GJ, Larco Jl, López-Serrano MC, López-Trascasa M, Marcos C, Muñoz-Caro JM, Pedrosa M, Prior N, Rubio M, Sala-Cunill A, SpanishStudyGrouponBradykinin-InducedAngioedema, GrupoEspañol de Estudio del Angioedema mediado por Bradicinina: Consensusstatementonthe diagnosis, management, and treatment of angioedema mediated by bradykinin. part I. classification, epidemiology, pathophysiology, genetics, clinical symptoms, and diagnosis. J Invest Allergol Clin Immunol 2011, 21:333-347.

18. Woodard-Grice AV, Lucisano AC, Byrd JB, Stone ER, Simmons WH, Brown NJ: Sex-dependent and race-dependent association of XPNPEP2 C-2399A polymorphism with angiotensin-converting enzyme inhibitor-associated angioedema. Pharmacogenet Genomics 2010, 20:532-536.

19. Mahmoudpour SH, Leusink M, van der Putten L, Terreehorst I, Asselbergs FW, de Boer A, Maitland-van der Zee AH: Pharmacogenetics of ACE inhibitorinduced angioedema and cough: a systematic review and meta-analysis. Pharmacogenomics 2013, 14:249-260.

20. Eriksson P, Kallin B, van'tHooft FM, Bavenholm P, Hamsten A: Allele-specific increase in basal transcription of plasminogen-activator inhibitor 1 gene is associated with myocardial infarction. Proc Natl Acad Sci U S A 1995, 92:1851-1855

21. Rossaak Jl, van Rij AM, Jones GT, Harris EL: Association of the $4 G / 5 G$ polymorphism in the promoter region of plasminogen activator inhibitor-1 with abdominal aortic aneurisms. J Vasc Surg 2000, 31:1026-1032.

22. Duan QL, Nikpoor B, Dube MP, Molinaro G, Meijer IA, Dion P, Rochefort D, Saint-Onge J, Flury L, Brown NJ, Gainer JV, Rouleau JL, Agostoni A, Cugno M, Simon P, Clavel P, Potier J, Wehbe B, Benarbia S, Marc-Aurele J, Chanard J, Foroud T, Adam A, Rouleau GA: A variant in XPNPEP2 is associated with angioedema induced by angiotensin I-converting enzyme inhibitors. Am J Hum Genet 2005, 77:617-626.

23. Rigat B, Hubert C, Alhenc-Gelas F, Cambien F, Corvol P, Soubrier F: An insertion/ deletion polymorphism in the angiotensin l-converting enzyme gene accounting for half the variance of serum enzyme levels. J Clin Invest 1990, 86:1343-1346.

24. Margaglione M, Grandone E, Cappucci G, Colaizzo D, Giuliani N, Vecchione G, d'Addedda M, Di Minno G: An alternative method for PAl-1 promoter polymorphism (4G/5G) typing. Thromb Haemost 1997, 77:605-606.

25. Nzeako UC, Frigas E, Tremaine WJ: Hereditary angioedema: a broad review for clinicians. Arch Intern Med 2001, 161:2417-2429.

26. Agostoni A, Aygören-Pürsün E, Binkley KE, Blanch A, Bork K, Bouillet $L$, Bucher C, Castaldo AJ, Cicardi M, Davis AE, De Carolis C, Drouet C, Duponchel C, Farkas H, Fáy K, Fekete B, Fischer B, Fontana L, Füst G, Giacomelli R, Gröner A, Hack CE, Harmat G, Jakenfelds J, Juers M, Kalmár L, Kaposi PN, Karádi I, Kitzinger A, Kollár T, et al: Hereditary and acquired angioedema: problems and progress: proceedings of the third C1 esterase inhibitor deficiency workshop and beyond. J Allerg Clin Immunol 2004, 114(Suppl 3):51-131.

27. Davis AE 3rd: Hereditary angioedema: a current state-of-the-art review, III: mechanisms of hereditary angioedema. Ann Allergy Asthma Immunol 2008, 100(Suppl 2):7-12.

28. Margaglione M, Cappucci G, d'Addedda M, Colaizzo D, Giuliani N, Vecchione G, Mascolo G, Grandone E, DiMinno G: PAl-1 plasma levels in a general population without clinical evidence of atherosclerosis: relation to environmental and genetic determinants. Arterioscler Thromb Vasc Biol 1998, 18:562-567.

29. Sekerli E, Katsanidis M, Papadopoulou V, Makedou A, Vavatsi N, Gatzola M, Eleni S, Dimitrios K, Vaya P, Areti M, Norma V, Magdalini G: Angiotensin-I converting enzyme gene and I/D polymorphism distribution in the Greek population and comparison with other European populations. J Genet 2008, 87:91-93.

30. NCBI, SNP Database [http://www.ncbi.nlm.nih.gov/projects/SNP/snp_ref. cgi?rs=3788853]

\section{Submit your next manuscript to BioMed Central and take full advantage of:}

- Convenient online submission

- Thorough peer review

- No space constraints or color figure charges

- Immediate publication on acceptance

- Inclusion in PubMed, CAS, Scopus and Google Scholar

- Research which is freely available for redistribution

Submit your manuscript at www.biomedcentral.com/submit
C Biomed Central 